\title{
IMPROVING THE QUALITY OF CUSTOMER SERVICE BY USING THE TECHNIQUE OF MYSTERY SHOPPING
}

\author{
Ludvík Eger ${ }^{1}$; Michal Mičík ${ }^{2}$ \\ University of West Bohemia, Faculty of Economics, \\ Department of Marketing, Trade and Services, \\ Univerzitní 8, 30614 Plzeň, Czech Republic \\ e-mail: ${ }^{1}$ leger@kmo.zcu.cz; ${ }^{2}$ micikm@kmo.zcu.cz
}

\begin{abstract}
This paper deals with the quality of customer service, especially with the importance of customer-oriented communication in selected industries of the Czech Republic. For excellent customer service, organizations must consistently check needs and wishes of their customers and the process of purchasing and working with customers (customer-oriented communication). The purpose of this study was to investigate the level of customer-oriented communication in differently specialized industries in the Czech Republic. The research was conducted in six regions (in small and in large cities/towns), which were chosen to represent level of customer-oriented communication in Czech shops. Research proved that over the last years, there has been a number of positive changes in sales. It also confirmed that in certain areas the communication with customers is better in smaller shops than in larger ones. The results can be of immense significance for the training of future business managers, educating sales force in terms of corporate training and improving the quality of sales.
\end{abstract}

\section{Introduction}

Mystery shopping is a specific technique suitable for evaluation of the shopping/buying process provided by trained shoppers who evaluate according to a scenario prepared in advance. Mystery shopping helps organizations to improve their customer service and to achieve their service standard. It can be used to measure customer's satisfaction on the one hand and as a starting point for training programmes and motivation of frontline employees on the other hand.

The purpose of this presented survey is to gain information about the level of customeroriented communication in retail and service providers in the Czech Republic.

Many important social changes have occurred in the Czech Republic over the past twenty years. The development of market economy within the European Union (since 2004) has significantly changed the requirements for quality of both retail and service and communication with customers. Organizations had to implement quality service standards and retrain their staff in communication with customers.

Shop sales persons and shop assistants work in the area where dynamic changes have occurred mainly in communication with customers. In the beginning, this change led to a discrepancy between how salespeople perceived themselves and what customers expected from them. There was an urgent need to change the behaviour patterns in the shopping/buying process [cf. 19].

The constantly appearing changes have been considerable for culture in society and obviously need to be reflected in the area of trade and services. Customer service and communication with customers became more important than they had been before [2], [15]. 
This probably unrepeatable situation has not been adequately described so far. We can find only several studies that partly explain this phenomenon. For example, Engle [4] explains how it was difficult in Central and Eastern Europe to recruit and to retrain new sale representatives. Vadi and Suuoroja [19] describe this issue only theoretically and present the Model of Customer-Oriented Communication. Djordjic [6] describes directly how it is possible to use mystery shopping and applies his methodological approach in financial services.

In the Czech Republic, Staňková and Vaculíková [18] construe the possibility of use of mystery shopping for improvement of trade and services only theoretically.

This research focuses on description of the customer service, especially on the importance of customer-oriented communication [2] in the Czech Republic, i.e. it is not just a partial study for a single company. The research is a part of the "customer-led busines" approach [17] that is focused on understanding the expressed desires of customers in their served markets. Findings of this survey help to understand changes in communication with customers in the field of trade and services. Moreover, the results can indicate weaknesses and show opportunities for staff development. The findings might be interesting for all who are involved in the trade and services in Central and Eastern Europe.

\section{$1 \quad$ Frontline employee and communication with customers}

Delivering quality customer service is essential to sustain any kind of business. Some studies show that up to $70 \%$ organizations are losing customers due to poor customer service and just less than $15 \%$ due to poor quality of the product (e.g. Michelson [14]).

Good relations with customers depend on two-way communication and excellent customer service, which can gain loyal customers who are willing to refer service to other people, possible future customers [1], [13], [15]. On the contrary, conflicts with customers can bring problems for business. Customer - employee interaction is a very important part of the service standards that organizations need to create, develop, maintain and evaluate.

What we need to consider when organization wants to improve a pattern of excellent customer service?

- To provide good customer service. The employees need to know what they are selling. Do they know how the product or service works? Are they able to answer common questions of the customers about a particular product or service? And how do they articulate the answer?

- To be friendly. Customer service starts with a smile and greeting. Especially in face-toface situations eye contact and a warm greeting is the first thing that customers see and hear. Do they greet customers?

- To listen to the wishes of customers. Listening and asking questions are key skills for interaction with customers. Listening is very important (not only verbal but also nonverbal). Are employees able to discover the needs and the wishes of customers?

- To be courteous and respectful. Customer service very often involves emotions. Are employees able to follow the rule: "Never let your own emotions overtake your desire."

- To thank the customers. Do they say thank you after every transaction? It is a very important habit in a good customer service.

- To learn from feedback. During the interview with the customers the employees receive a lot of information about a customer's needs. Do they know what customers think about 
their business, products and services? Are they able to collect the important information and to shift feedbacks to the management?

- To develop negotiation with customers. Good negotiations contribute to business success and support growing of the sales. Strong negotiators are excellent at interpersonal communication skills and create confidence. Are employees able to establish long-term relationships with customers?

- To improve staff training and staff support. Does the organization provide employees' training that helps them to carry out good customer service through the customer experience?

The important points mentioned above underline the fact that organizations need to do something with feedback from customers if they want to improve their business and customer-oriented communication as a part of customer service. They need to identify areas for improvement and afterwards be able to make specific changes. Mystery shopping is a suitable technique for this task. For excellent customer service, organizations must consistently check their customers' needs and wishes and the process of purchasing and working with customers (customer-oriented communication).

\section{$2 \quad$ Mystery shopping}

Mystery shopping is a technique that is used by trade organizations to measure service experience. "Mystery shopping is a process for measuring service quality, with feedback, that is understandable to the frontline people in retailing." [16, p. 54] This technique is very useful to map and to evaluate communication between shop sales persons or shop assistants and the customers. ESOMAR [5] states: "The purpose of mystery shopping studies is to help focus on the attention of business management on customer service improvement by providing information on the operation and the quality of service that is provided."

Mystery shopping is an effective technique for assessing employee friendliness and helpfulness. From the customer's point of view, this technique is also very useful and objective as for evaluating cleanliness of the facility, waiting time, commercial signage, adherence to the organization standard and communication with them.

Mystery shopping results lead to improvement of the service process and mostly it is an initial point for the learning process and new staff training programme. Ford, Latham, and Lennox [7] underline that mystery shopping provides third-party data for managers who can use results of mystery shopping when coaching their employees. If used appropriately, mystery shopping results can be also part of the motivation process and can improve the level of service standard via subsequent goals settings in relation to communication with customers and the level of service standard.

In the trade it is not easy and not as common to measure quality as in manufacturing firms. Services need evaluation of their customers' expectations. Mystery shopping is a technique that simulates and checks sale process and communication with customers.

Mystery shoppers must follow specific guidelines. Skilled mystery shoppers can make a relatively objective assessment of all observed aspects of the service experience. He or she goes "incognito" to a shopping point (specific shop) to examine the service process and the way shop assistants/salespeople communicate with customers. He or she acts as a typical customer and evaluates predetermined service standards that are an important part of the service quality. The task is usually to buy a product or a service and to meet employees (e.g. shop assistants, shop sales persons) delivering the service. In our case special attention is paid to mapping communication with the customer by means of a mystery shopper. 
The control sheet or the comment card is designed to measure various aspects of the processes that usually have a relation to specific service standards.

Because trained and skilled mystery shoppers use the same measures for every shop/organization, the results of mystery shopping can be used to compare effectiveness of customer service across sales units.

Mystery shoppers' programmes are typical for organizations where communication with customers is very important. The management needs to control standards or quality of the service process. Analyses of the results of mystery shopping over time enables managers to discover whether the service quality delivery is improving or not. Some authors recommend using the data only for assessing the performance on organizational level and not for individual units or specific employees [7], [9]. We advocate the opposite opinion. If an organization uses mystery shopping on a regular basis, there is a possibility to evaluate units regularly and use the results of mystery shopping as feedback of the employees' work. For management, the following questions are important: Do employees meet service standards? How do they offer our products? Are the customers satisfied with the communication?

Mystery shopping is also a research method used to gather information about a shop's "frontline" [14], [16]. Our research deals with the description and evaluation of the communication with customers during the process of purchasing in selected industries in the Czech Republic.

\section{$3 \quad$ Methodology}

The purpose of this research study is to investigate the level of customer-oriented communication in differently specialized industries in the Czech Republic. Customer-oriented communication is an important part of shop salespeople and shop assistants performance and helps organizations to improve their services.

The chosen approach in research is descriptive (initially mapping of the field) and explorative (clarifying differences in customer-oriented communication as a part of service standard in differently sized units and in differently specialized industries).

\subsection{Research questions}

The survey research provides answers to the central research question: "What is the level of customer-oriented communication in selected industries in the Czech Republic?"

In addition to the central research question based on the desk research results we formulated another research sub-questions:

- Do shop salespeople / shop assistants know how the product or service works?

- Are shop sales persons / shops assistants friendly to customers?

- Are they able to listen and ask questions during interview with customers?

- Are there any differences in dealing with customers and in the level of service provided across researched industries?

\subsection{Research method and tools}

For the planned research, a technique that is a combination of observation and interview was chosen [8], [12]. This special technique of data collection is called mystery shopping (mystery visit and mystery observation). The above mentioned technique splits into two basic data collection methods, covert observation and semi structured interview. 
Mystery shoppers (students of a university study programme focused on trade and services) were first given instructions about the scenario they had to follow, i.e. these students were trained for managing customer service including the implementation of mystery shopping programme in different organizations.

The research was conducted in six regions (in small and in large cities/towns), which were selected to represent the level of customer-oriented communication in Czech shops.

The scenario was based on the topics in the theoretical part [5], [7], [16], [18], [20]. Its structure and the content were prepared according to the mentioned research and two similar control sheets that were used by two international companies to check communication of their employees with customers. The scenario contains $25+1$ items divided into areas:

- Shop interior, staff appearance and product presentation

- Customer service and product offering

The research study was realized professionally and with appropriate data security. The gained data were anonymized and were used for research and training purposes only.

The research covers 3 different industries in the Czech Republic:

- Electronics and communication equipments (74)

- Clothing and shoes (95)

- Household goods and drugstore (43)

The total amount of all shops was 212. These shops were divided into two groups - small and large sized shops; based on the number of their business units $(<5$ small sized, $>5$ large sized). A group of small sized shops consists of 47 shops and a group of large sized POS (point of sale) consists of 165 shops.

\section{$4 \quad$ Findings}

In every table in this article there is an absolute value followed by a relative value of every given item.

In tables 1, 2 and 3, the scale value "Not quite" was not taken for items 3 and 5.

Central tendency for items 2, 6, 8 and 10 is "Not quite", for item 1 "Yes, not organized", for item 7 "Mostly", and for item 9 "To request - not immediately".

Table 1 compares small sized shops with large sized shops in the manner of shop interior, staff appearance and product presentation. 
Tab. 1: Shop interior, staff appearance and product presentation in small and large sized shops

\begin{tabular}{|c|c|c|c|c|c|c|c|c|c|c|c|c|c|}
\hline \multirow{2}{*}{\multicolumn{2}{|c|}{ Items }} & \multicolumn{6}{|c|}{ Small sized shops } & \multicolumn{6}{|c|}{ Large sized shops } \\
\hline & & \multicolumn{2}{|r|}{ Yes } & \multicolumn{2}{|c|}{ Not quite } & \multicolumn{2}{|r|}{ No } & \multicolumn{2}{|r|}{ Yes } & \multicolumn{2}{|c|}{ Not quite } & \multicolumn{2}{|r|}{ No } \\
\hline 1 & Were there flyers in the shop? & 23 & $48.94 \%$ & 1 & $2.12 \%$ & 23 & $48.94 \%$ & 103 & $62.42 \%$ & 9 & $5.45 \%$ & 53 & $32.13 \%$ \\
\hline 2 & $\begin{array}{l}\text { Was the floor free of dirt and did it appear } \\
\text { clean? }\end{array}$ & 44 & $93.62 \%$ & 3 & $6.38 \%$ & 0 & $0.00 \%$ & 154 & $93.33 \%$ & 11 & $6.67 \%$ & 0 & $0.00 \%$ \\
\hline 3 & Were the shelves well-organized? & 44 & $93.62 \%$ & & & 3 & $6.38 \%$ & 163 & $98.79 \%$ & & & 2 & $1.21 \%$ \\
\hline 4 & $\begin{array}{l}\text { Was the staff's appearance appropriate to the } \\
\text { nature of the shop? }\end{array}$ & 26 & $55.32 \%$ & 21 & $44.68 \%$ & 0 & $0.00 \%$ & 118 & $71.52 \%$ & 47 & $28.48 \%$ & 0 & $0.00 \%$ \\
\hline 5 & $\begin{array}{l}\text { Were the staff members easily recognizable } \\
\text { with a uniform or name tags? }\end{array}$ & 8 & $17.02 \%$ & & & 39 & $82.98 \%$ & 110 & $66.67 \%$ & & & 55 & $32.33 \%$ \\
\hline 6 & Were the products displayed neatly? & 31 & $65.96 \%$ & 16 & $34.04 \%$ & 0 & $0.00 \%$ & 142 & $86.06 \%$ & 22 & $13.33 \%$ & 1 & $0.61 \%$ \\
\hline 7 & Were the products labeled with prices? & 35 & $74.46 \%$ & 10 & $21.28 \%$ & 2 & $4.26 \%$ & 144 & $87.27 \%$ & 20 & $12.12 \%$ & 1 & $0.61 \%$ \\
\hline 8 & $\begin{array}{l}\text { Did you have enough personal space at the cash } \\
\text { desk? (e.g. other people did not bump into you) }\end{array}$ & 43 & $91.49 \%$ & 4 & $8.51 \%$ & 0 & $0.00 \%$ & 159 & $96.36 \%$ & 6 & $3.64 \%$ & 0 & $0.00 \%$ \\
\hline 9 & $\begin{array}{l}\text { Did you receive a receipt and/or a warranty } \\
\text { card? }\end{array}$ & 44 & $93.62 \%$ & 0 & $0.00 \%$ & 3 & $6.38 \%$ & 163 & $98.79 \%$ & 2 & $1.21 \%$ & 0 & $0.00 \%$ \\
\hline 10 & Was the product well packed? & 38 & $80.85 \%$ & 3 & $6.38 \%$ & 6 & $12.77 \%$ & 150 & $90.91 \%$ & 10 & $6.06 \%$ & 5 & $3.03 \%$ \\
\hline
\end{tabular}

Source: Own

Partial conclusions are as follows.

- In almost half of the shops, the POS materials were not used right to attract the customers' attention and to ultimately influence his or her final purchasing decisions. This statistic applies to both small and large sized shops, as can be seen from Table 1 (item 1).

- It is a gratifying fact, that almost every shop was described as clean (item 2).

- Problems with the staff's appearance and their identification were found in small sized shops (items 4 and 5).

- There are opportunities for improvements in areas of price presentation and product packing. This applies to both small and large sized shops, particularly for small sized ones, which will be clarified later in the text.

To better understand the collected data, second sorting criterion was added. All shops were divided into 3 industries. For a more thorough analysis, industries of Electronics and communication equipment, Clothing and shoes and Household goods and drugstores were used.

The purpose of adding the second criteria was to find out if differences in mystery shopping outcomes between individual industries exist independently of size of the shop.

Tab. 2: Shop interior, staff appearance and product presentation in chosen industries, part 1

\begin{tabular}{|c|c|c|c|c|c|c|c|c|c|c|c|c|c|}
\hline \multirow{2}{*}{\multicolumn{2}{|c|}{ Items }} & \multicolumn{6}{|c|}{ Electronics and communication equipment } & \multicolumn{6}{|c|}{ Clothing and shoes } \\
\hline & & \multicolumn{2}{|c|}{ Yes } & \multicolumn{2}{|c|}{ Not quite } & \multicolumn{2}{|r|}{ No } & \multicolumn{2}{|r|}{ Yes } & \multicolumn{2}{|c|}{ Not quite } & \multicolumn{2}{|r|}{ No } \\
\hline 1 & Were there flyers in the shop? & 61 & $82.43 \%$ & 2 & $2.70 \%$ & 11 & $14.86 \%$ & 39 & $41.05 \%$ & 5 & $5.26 \%$ & 51 & $53.68 \%$ \\
\hline 2 & $\begin{array}{l}\text { Was the floor free of dirt and appeared } \\
\text { clean? }\end{array}$ & 66 & $89.19 \%$ & 8 & $10.81 \%$ & 0 & $0.00 \%$ & 91 & $95.79 \%$ & 4 & $4.21 \%$ & 0 & $0.00 \%$ \\
\hline 3 & Were the shelves well-organized? & 72 & $97.30 \%$ & & & 2 & $2.70 \%$ & 93 & $97.89 \%$ & & & 2 & $2.11 \%$ \\
\hline 4 & $\begin{array}{l}\text { Was the staff's appearance appropriate to the } \\
\text { nature of the shop? }\end{array}$ & 41 & $55.41 \%$ & 33 & $44.59 \%$ & 0 & $0.00 \%$ & 76 & $80.00 \%$ & 19 & $20.00 \%$ & 0 & $0.00 \%$ \\
\hline 5 & $\begin{array}{l}\text { Were the staff members easily recognizable } \\
\text { with uniform or name tags? }\end{array}$ & 49 & $66.22 \%$ & & & 25 & $33.78 \%$ & 49 & $51.58 \%$ & & & 46 & $48.42 \%$ \\
\hline 6 & Were the products displayed neatly? & 58 & $78.38 \%$ & 16 & $21.62 \%$ & 0 & $0.00 \%$ & 84 & $88.42 \%$ & 11 & $11.58 \%$ & 0 & $0.00 \%$ \\
\hline 7 & Were the products & 67 & $90.54 \%$ & 4 & $5.41 \%$ & 3 & $4.05 \%$ & 86 & $90.53 \%$ & 9 & $9.47 \%$ & 0 & $0.00 \%$ \\
\hline 8 & $\begin{array}{l}\text { Did you have enough personal space at the } \\
\text { cash desk? (e.g. other people did not bump } \\
\text { into you) }\end{array}$ & 70 & $94.59 \%$ & 4 & $5.41 \%$ & 0 & $0.00 \%$ & 94 & $98.95 \%$ & 1 & $1.05 \%$ & 0 & $0.00 \%$ \\
\hline 9 & $\begin{array}{l}\text { Did you receive a receipt and/or a warranty } \\
\text { card? }\end{array}$ & 73 & $98.65 \%$ & 0 & $0.00 \%$ & 1 & $1.35 \%$ & 94 & $98.95 \%$ & 0 & $0.00 \%$ & 1 & $1.05 \%$ \\
\hline 10 & Was the product well packed? & 63 & $85.14 \%$ & 4 & $5.41 \%$ & 7 & $9.46 \%$ & 93 & $97.89 \%$ & 2 & $2.11 \%$ & 0 & $0.00 \%$ \\
\hline
\end{tabular}

Source: Own 
Tab. 3: Shop interior, staff appearance and product presentation in chosen industries, part 2

\begin{tabular}{|c|c|c|c|c|c|c|c|}
\hline \multirow{2}{*}{\multicolumn{2}{|c|}{ Items }} & \multicolumn{6}{|c|}{ Household goods and drugstore } \\
\hline & & \multicolumn{2}{|r|}{ Yes } & \multicolumn{2}{|c|}{ Not quite } & \multicolumn{2}{|c|}{ No } \\
\hline $\mathbf{1}$ & Were there flyers in the shop? & 26 & $60.47 \%$ & 3 & $6.98 \%$ & 14 & $32.56 \%$ \\
\hline 2 & Was the floor free of dirt and appeared clean? & 41 & $95.35 \%$ & 2 & $4.65 \%$ & 0 & $0.00 \%$ \\
\hline 3 & Were the shelves well-organized? & 42 & $97.67 \%$ & & & 1 & $2.33 \%$ \\
\hline 4 & Was the staff's appearance appropriate to the nature of the shop? & 27 & $62.79 \%$ & 16 & $37.21 \%$ & 0 & $0.00 \%$ \\
\hline 5 & Were the staff members easily recognizable with uniform or name tags? & 20 & $46.51 \%$ & & & 23 & $53.49 \%$ \\
\hline 6 & Were the products displayed neatly? & 31 & $72.09 \%$ & 11 & $25.58 \%$ & 1 & $2.33 \%$ \\
\hline 7 & Were the products labeled with prices? & 26 & $60.47 \%$ & 17 & $39.53 \%$ & 0 & $0.00 \%$ \\
\hline 8 & $\begin{array}{l}\text { Did you have enough personal space at the cash desk? (e.g. other people did not bump into } \\
\text { you) }\end{array}$ & 38 & $88.37 \%$ & 5 & $11.63 \%$ & 0 & $0.00 \%$ \\
\hline 9 & Did you receive a receipt and/or a warranty card? & 40 & $93.02 \%$ & 2 & $4.65 \%$ & 1 & $2.33 \%$ \\
\hline 10 & Was the product well packed? & 32 & $74.42 \%$ & 7 & $16.28 \%$ & 4 & $9.30 \%$ \\
\hline
\end{tabular}

Source: Own

Partial conclusions are as follows.

- As can be seen from table 2, the worst situation regarding the POS materials occurred in the industry of Clothing and shoes (item 1).

- Opportunities for improvement as for appearance and identification of staff exist in all industries.

- In the Household goods and drugstore industry, the issue with price presentation is significant, as shown in Table 3 (item 7).

- No major problem was found in paying at the cash desk in all industries, the same applies to getting a receipt after making a purchase.

- Packing a product seems to be a problem in the Household goods and drugstore industry and Electronics and communication equipment.

Tables 4 and 5, which follow in the text below, show how members of staff were able to interact with customers. By means of a control sheet, mystery shoppers did not just evaluate staff's ability to communicate. Among other things, he or she were also finding out whether the staff was able to greet customers, ask well-aimed questions to get enough information about the customer's needs to recommend a suitable product, offer accessories and thank for the purchase. Results for small and large sized shops can be seen in table 4; table 5 shows more thorough analysis of selected industries. The selection of industries and purpose of this selection remains the same as it was explained earlier in the text.

In Tables 4 and 5 an absolute value followed by a relative value of every item is given again.

Tab. 4: Interaction of salespeople with customers in small and large sized shops

\begin{tabular}{|c|c|c|c|c|c|c|c|c|c|}
\hline \multirow{2}{*}{\multicolumn{2}{|c|}{ Items }} & \multicolumn{4}{|c|}{ Small sized shops } & \multicolumn{4}{|c|}{ Large sized shops } \\
\hline & & \multicolumn{2}{|r|}{ Yes } & \multicolumn{2}{|c|}{ No } & \multicolumn{2}{|r|}{ Yes } & \multicolumn{2}{|c|}{ No } \\
\hline 11 & Did the shop assistant make eye contact when you entered the shop? & 42 & $89.36 \%$ & 5 & $10.64 \%$ & 126 & $76.36 \%$ & 39 & $23.64 \%$ \\
\hline 12 & Did the shop assistant smile? & 34 & $72.34 \%$ & 13 & $27.66 \%$ & 98 & $59.39 \%$ & 67 & $40.61 \%$ \\
\hline 13 & Were you approached by the shop assistant within 4 minutes? & 36 & $76.60 \%$ & 11 & $23.40 \%$ & 109 & $66.06 \%$ & 56 & $33.94 \%$ \\
\hline 14 & Were you greeted? & 45 & $95.74 \%$ & 2 & $4.26 \%$ & 153 & $92.73 \%$ & 12 & $7.27 \%$ \\
\hline 15 & Did the shop assistant ask you an open question in the beginning? & 41 & $87.23 \%$ & 6 & $12.77 \%$ & 104 & $63.03 \%$ & 61 & $36.97 \%$ \\
\hline 16 & $\begin{array}{l}\text { Was the eye contact maintained by the shop assistant during your } \\
\text { conversation? }\end{array}$ & 43 & $91.49 \%$ & 4 & $8.51 \%$ & 134 & $81.21 \%$ & 31 & $18.79 \%$ \\
\hline 17 & Did the shop assistant ask you questions to clarify your needs? & 25 & $53.19 \%$ & 22 & $46.81 \%$ & 79 & $47.88 \%$ & 86 & $52.12 \%$ \\
\hline 18 & Were you asked additional questions to specify a product for you? & 27 & $57.45 \%$ & 20 & $42.55 \%$ & 82 & $49.70 \%$ & 83 & $50.30 \%$ \\
\hline 19 & Were you asked about the price range? & 16 & $34.04 \%$ & 31 & $65.96 \%$ & 45 & $27.27 \%$ & 120 & $72.73 \%$ \\
\hline 20 & Were the benefits of the product for the customer emphasized? & 26 & $55.32 \%$ & 21 & $44.68 \%$ & 71 & $43.03 \%$ & 94 & $56.97 \%$ \\
\hline 21 & Did the assistant know answers to additional questions you asked? & 46 & $97.87 \%$ & 1 & $2.13 \%$ & 148 & $89.70 \%$ & 17 & $10.30 \%$ \\
\hline 22 & Did the shop sales person thank you upon completion of your purchase? & 33 & $70.21 \%$ & 14 & $29.79 \%$ & 123 & $74.55 \%$ & 42 & $25.45 \%$ \\
\hline 23 & Did the shop sales person ask you if they could do something else for you? & 24 & $51.06 \%$ & 23 & $48.94 \%$ & 89 & $53.94 \%$ & 76 & $46.06 \%$ \\
\hline 24 & Were you offered accessories? & 20 & $42.55 \%$ & 27 & $57.45 \%$ & 80 & $48.48 \%$ & 85 & $51.52 \%$ \\
\hline 25 & Was the staff in the shop patient? & 42 & $89.36 \%$ & 5 & $10.64 \%$ & 149 & $90.30 \%$ & 16 & $9.70 \%$ \\
\hline
\end{tabular}

Source: Own 
Partial conclusions are as follows.

- Making contact, smiling and greeting customers is more common in small sized shops (items $11-14$ and 16).

- Asking a suitable open question in the beginning is one of the basic business skills. As can be seen in Table 4, slightly better results were achieved by small sized shops (item 15).

- The research outcomes point out a serious issue of not asking questions about the customer's needs and wishes (item 17). In addition to that, almost 50\% of staff members do not ask any further questions to specify a product for a customer (item 18). These facts apply both to small and large sized shops.

- Even worse results were achieved in a question about the price range (item 19). That could be caused by the nature of a product.

- Staff members were able to answer additional questions. On the other hand, a significant part of them was not able or willing to introduce the product's benefits. That is a serious issue.

- Thanking can be seen as an opportunity to improve (item 22) along with the offering of accessories and asking for an additional wish - only approximately 50\% of shop salespeople asked if there was anything else they could do for a customer. We find this number inadequate.

Tab. 5: Interaction of salespeople with customers in chosen industries

\begin{tabular}{|c|c|c|c|c|c|c|c|c|c|c|c|c|c|}
\hline \multirow{2}{*}{\multicolumn{2}{|c|}{ Items }} & \multicolumn{4}{|c|}{$\begin{array}{c}\text { Electronics and } \\
\text { communication equipment }\end{array}$} & \multicolumn{4}{|c|}{ Clothing and shoes } & \multicolumn{4}{|c|}{$\begin{array}{c}\begin{array}{c}\text { Household goods and } \\
\text { drugstore }\end{array} \\
\end{array}$} \\
\hline & & \multicolumn{2}{|c|}{ Yes } & \multicolumn{2}{|c|}{ No } & \multicolumn{2}{|c|}{ Yes } & \multicolumn{2}{|r|}{ No } & \multicolumn{2}{|c|}{ Yes } & \multicolumn{2}{|c|}{ No } \\
\hline 11 & $\begin{array}{l}\text { Did the shop assistant make eye } \\
\text { contact when you entered the } \\
\text { shop? }\end{array}$ & 57 & $77.03 \%$ & 17 & $22.97 \%$ & 75 & $78.95 \%$ & 20 & $21.05 \%$ & 36 & $83.72 \%$ & 7 & $16.28 \%$ \\
\hline 12 & Did the shop assistant smile? & 42 & $56.76 \%$ & 32 & $43.24 \%$ & 66 & $69.47 \%$ & 29 & $30.53 \%$ & 24 & $55.81 \%$ & 19 & $44.19 \%$ \\
\hline 13 & \begin{tabular}{|l|} 
Were you approached by the \\
shop assistant within 4 minutes?
\end{tabular} & 56 & $75.68 \%$ & 18 & $24.32 \%$ & 58 & $61.05 \%$ & 37 & $38.95 \%$ & 31 & $72.09 \%$ & 12 & $27.91 \%$ \\
\hline 14 & Were you greeted? & 70 & $94.59 \%$ & 4 & $5.41 \%$ & 88 & $92.63 \%$ & 7 & $7.37 \%$ & 40 & $93.02 \%$ & 3 & $6.98 \%$ \\
\hline 15 & $\begin{array}{l}\text { Did the shop assistant ask you an } \\
\text { open question in the beginning? }\end{array}$ & 60 & $81.08 \%$ & 14 & $18.92 \%$ & 57 & $60.00 \%$ & 38 & $40.00 \%$ & 28 & $65.12 \%$ & 15 & $34.88 \%$ \\
\hline 16 & $\begin{array}{l}\text { Was the eye contact maintained } \\
\text { by the shop assistant during your } \\
\text { conversation? }\end{array}$ & 66 & $89.19 \%$ & 8 & $10.81 \%$ & 77 & $81.05 \%$ & 18 & $18.95 \%$ & 34 & $79.07 \%$ & 9 & $20.93 \%$ \\
\hline 17 & $\begin{array}{l}\text { Did the shop assistant ask you } \\
\text { questions to clarify your needs? }\end{array}$ & 36 & $48.65 \%$ & 38 & $51.35 \%$ & 42 & $44.21 \%$ & 53 & $55.79 \%$ & 26 & $60.47 \%$ & 17 & $39.53 \%$ \\
\hline 18 & $\begin{array}{l}\text { Were you asked additional } \\
\text { questions to specify a product } \\
\text { for you? }\end{array}$ & 36 & $48.65 \%$ & 38 & $51.35 \%$ & 46 & $48.42 \%$ & 49 & $51.58 \%$ & 27 & $62.79 \%$ & 16 & $37.21 \%$ \\
\hline 19 & $\begin{array}{l}\text { Were you asked about the price } \\
\text { range? }\end{array}$ & 34 & $45.95 \%$ & 40 & $54.05 \%$ & 14 & $14.74 \%$ & 81 & $85.26 \%$ & 13 & $30.23 \%$ & 30 & $69.77 \%$ \\
\hline 20 & $\begin{array}{l}\text { Were the benefits of the product } \\
\text { for the customer emphasized? }\end{array}$ & 39 & $52.70 \%$ & 35 & $47.30 \%$ & 32 & $33.68 \%$ & 63 & $66.32 \%$ & 26 & $60.47 \%$ & 17 & $39.53 \%$ \\
\hline 21 & $\begin{array}{l}\text { Did the assistant know answers } \\
\text { to additional questions you } \\
\text { asked? }\end{array}$ & 64 & $86.49 \%$ & 10 & $13.51 \%$ & 89 & $93.68 \%$ & 6 & $6.32 \%$ & 41 & $95.35 \%$ & 2 & $4.65 \%$ \\
\hline 22 & $\begin{array}{l}\text { Did the shop sales person thank } \\
\text { you upon completion of your } \\
\text { purchase? }\end{array}$ & 52 & $70.27 \%$ & 22 & $29.73 \%$ & 77 & $81.05 \%$ & 18 & $18.95 \%$ & 27 & $62.79 \%$ & 16 & $37.21 \%$ \\
\hline 23 & $\begin{array}{l}\text { Did the shop sales person ask } \\
\text { you if they could do something } \\
\text { else for you? }\end{array}$ & 35 & $47.30 \%$ & 39 & $52.70 \%$ & 61 & $64.21 \%$ & 34 & $35.79 \%$ & 17 & $39.53 \%$ & 26 & $60.47 \%$ \\
\hline 24 & Were you offered accessories? & 22 & $29.73 \%$ & 52 & $70.27 \%$ & 60 & $63.16 \%$ & 35 & $36.84 \%$ & 18 & $41.86 \%$ & 25 & $58.14 \%$ \\
\hline 25 & $\begin{array}{l}\text { Was the staff in the shop } \\
\text { patient? }\end{array}$ & 64 & $86.49 \%$ & 10 & $13.51 \%$ & 90 & $94.74 \%$ & 5 & $5.26 \%$ & 37 & $86.05 \%$ & 6 & $13.95 \%$ \\
\hline
\end{tabular}

Source: own

Partial conclusions are as follows. 
When comparing results of customer service and product offering in selected industries, following facts can be stated:

- Smiling upon a customer is not a common habit in the Czech Republic. With a proper training, employees can learn how to improve themselves in making contact.

- As already mentioned above, there is lack of questions about customers' needs and wishes. Staff members also don't ask questions to specify the price range.

- Best results in thanking and offering accessories were achieved in the Clothing and shoes industry.

The additional item $(+1)$ not shown in Tables 4 and 5 was a question, whether a customer understood a shop assistant's language or not (e.g. use of slang, technical terms, ...). In 90\% of cases, in both small and large sized shops the customers were able to understand, $9.5 \%$ of customers had minor difficulties to understand and only $0.5 \%$ of all customers had major difficulties to understand.

\section{Conclusion}

The presented study goes far beyond the theoretical definition of the term 'mystery shopping' as a method for marketing research [16], [18] or the theoretical model of a salespeople training programme [19]. With total amount of 212 samples of Mystery Shoppings in six regions in selected industries in the Czech Republic, the research provides outputs that can be generalized to some extent in selected industries for the whole country.

The results of this coordinated action research are not just a partial study for a chosen organization. They represent a comprehensive view on the level of customer-oriented communication in retail in selected industries of in Czech Republic. That being said, the results can be of immense significance for a training of future business managers, educating sales force in terms of corporate training and improving a quality of sales.

Research proved that over the last years, there has been a number of positive changes in sales (shop cleanliness, customer's addressing, employee's clothing and identification in large sized shops, product labeling, etc.) Research also confirmed that in certain areas the communication with customers is better in smaller shops than in larger ones and that employees are closer to customers in terms of interaction in smaller shops rather than they are in larger shops. Here it is possible to discuss research results in the context of assessing the impact of marketing in multinational subsidiaries [11].

Comparison of selected industries showed that in practice it is advisable to pay attention to the industry where the shop operates. The differences between three industries were presented, since other industries could not be used due to a small number of records. If used, data comparison would not be relevant and results would be distorted. Especially focus on customer-oriented communication could be considered as another limitation of the research, since mystery shopping is used for a wide variety of purposes worldwide [7], [10], [14], [16].

Compared with a pilot study from the Czech Republic [3], the results of the research unfortunately showed persistent difficulties in communication with customers, particularly in initiating the first contact, questioning the needs and desires of customers and offering additional products and services. Benefits for organizations resulting from this research can be mentioned; outputs show that the opportunities to improve not just skills and motivation, but also other qualities of sales force exist. If we admit that the statement "Effective communication is an important part of business success" is true, then, with proper training, 
sales, profit and customer's satisfaction can be increased, and, with appropriately chosen motivational tools, employee satisfaction can be increased, too.

\section{Literature}

[1] AMOS, C.; HOLMES, R. G.; KENESON, C. W.: A meta-analysis of customer impulse buying. Journal of Retail and Consumer Service. 2014, Vol. 21, Issue. 2, pp. 86-97. ISSN 0969-6989.

[2] BENEKE, J.; HAYWORTH, C.; HOBSON, R; MIA, Z.: Examining the effect of retail service quality dimensions on customer satisfaction and loyalty: The case of the supermarket shopper. ActaCommercii. 2012. Vol. 12, Issue.1, pp. 27-43. ISSN 16807537.

[3] EGER, L.: Osobní prodej - co zlepšit v tréninku prodejní síly? Marketing \& komunikace. 2009, Vol. 14, Issue. 1, pp. 27-28. ISSN 1211-5622.

[4] ENGLE, R.: Multi-step, Structured Interviews to Select Sales Representatives in Russia and Eastern Europe. European Management Journal. 1998. Vol. 16, Issue. 4, pp. 476484. ISSN 0263-2373.

[5] ESOMAR: Codes and Guidelines. Mystery shopping studies. [online]. 2005. [accessed 2015-01-30]. Available from WWW: http://www.esomar.org/knowledge-andstandards/codes-and-guidelines.php

[6] DJORDJIC, M.: Specificities of Mystery Shopping in Retail Financial Services. Časopisza marketing teoriju i praksu. Quarterly Marketing Journal. 2011. Vol. 42, Issue. 1, pp. 53-69. ISSN 0354-3471.

[7] FORD, C. R.; LATHAM, P. G.; LENNOX, G.: Mystery shoppers: A new tool for coaching employee performance improvement. Organizational Dynamics. 2011. Vol. 40, pp. 157-164. ISSN 0090-2616.

[8] GRAY, E. D.: Doing Research in the Real Word. London: SAGE. 2009. ISBN 978-184787-336-1.

[9] GUENZI, P.; BALDAUF, A.; PNAGOPOUlOS, G. N.: The influence of formal and informal sales control-directed selling behaviors and sales unit effectiveness. Industrial Management Marketing. 2014. Vol. 43, pp. 786-800. ISSN 0019-8501.

[10] HESSELINK, M.; Van der WIELE, T.: Mystery Shoping: In-depth measurement of customer satisfaction. [online]. ERIM Report Series Research in Management, ERS2003-020-ORG. Rotterdam, March, 2003. [accessed 2015-01-30]. Available from WWW: http://papers.ssrn.com/sol3/papers.cfm?abstract_id=411653

[11] KARLÍČEK, M.; CHYTKOVÁ, Z.; HOŘEJŠÍ, N.; MOHELSKÁ, H.; FISCHER, J.: The role of marketing in multinational subsidiaries: standardization versus localization. E+M Ekonomie a Management. 2013. Vol. 16, Issue. 1, pp. 138-148. ISSN 1212-3609.

[12] KINNEAR, C. T.; TAYLOR, R. J.: Marketing Research an applied approach. New York: McGraw-Hill.1991. ISBN 0-07-034757-3.

[13] KOTLER, P.; KELLER, L. K.: Marketing Management. Boston: Pearson Education. 2012, ISBN 978-0-273-75502-9.

[14] MICHELSON Associates, Inc.: Mystery Shopping.[online]. [accessed 2015-03-15]. Available from WWW: http://www.michelson.com/mystery/ 
[15] PARMENT, A.: Genration Y vs. Baby Boomers: Shopping behavior, buyer involvement and implication for retailing. Journal of Retail and Consumer Service. 2013, Vol. 20, Issue. 2, pp. 189-199. ISSN 0969-6989.

[16] SCHMIDT, J. M.; HOLLENSEN, S.: Marketing Research an International Approaches. Harlow: Pearson. 2006. ISBN 10: 0273646354.

[17] SLATER, F. S.; NARVER, C. J.: Research notes and communications customer-led and market oriented: Let's not confuse the two. Strategic Management Journal. 1998, Vol. 19, Issue 10, pp. 1001-1006. ISSN 0143-2095.

[18] STAŇKOVÁ, P.; VACULÍKOVÁ, M.: Mystery Shopping as an Instrument of Marketing research. E+M Ekonomie a Management. 2007. Vol. 10, Issue. 1, pp. 108113. ISSN 1212-3609.

[19] VADI, M.; SUUROJA, M.: (2006) Training retail sales personnel in transition economies: Applying model of customer-oriented communication. Journal of Retailing and Consumer Services. Vol. 13, Issue 5, pp. 339-349. ISSN 0969-6989.

[20] WILSON, M. A.: The Use of Mystery Shopping in the Measurement of Service Delivery. The Service Industries Journal. 1998, Vol. 19, Issue 3, pp. 148-163. ISSN 0264-2069.

doc. PaedDr. Ludvík Eger, CSc.; Ing. Michal Mičík 


\section{ZLEPŠOVÁNÍ KVALITY SLUŽEB ZÁKAZNÍKŮM POUŽÍVÁNÍM TECHNIKY MYSTERY SHOPPING}

Př́spěvek je zaměřen na kvalitu služeb poskytovanou zákazníkům a speciálně na zákaznicky orientovanou komunikaci při prodeji v České republice. Pro poskytování excelentních služeb musí organizace průběžně zjišt’ovat potřeby a přání zákazníků a kontrolovat prodejní proces včetně komunikace orientované na zákazníky. Účelem výzkumné studie bylo zjistit úroveň komunikace se zákazníky ve vybraných oblastech obchodu v České republice. Výzkum byl realizován $\mathrm{v}$ šesti regionech $\mathrm{v}$ malých i velkých městech $\mathrm{v}$ obchodech, které byly vybrány pro zjištění úrovně zákaznicky orientované komunikace. Výstupy výzkumu ukazují, že za poslední roky došlo k pozitivním změnám v úrovni prodeje. Bylo také potvrzeno, že komunikace se zákazníky je lepší v malých obchodech proti velkým obchodům. Výsledky jsou významné pro management prodeje v zaměření na zlepšování prodeje. Využitelné jsou pro trénink prodejní síly a pro zlepšování kvality prodeje.

\section{VERBESSERUNG DER QUALITÄT VON DIENSTLEISTUNGEN MIT HILFE DER TECHNIK MYSTERY SHOPPING}

Dieser Beitrag befasst sich mit der Qualität von Dienstleistungen, speziell mit der kundenorientierten Kommunikation beim Verkauf in der Tschechischen Republik. Für die Gewährleistung exzellenter Dienstleistungen müssen die Organisationen durchlaufend die Befriedigung der Bedürfnisse und Wünsche der Kunden sicherstellen und den Verkaufsprozess inklusive der kundenorientierten Kommunikation im Auge behalten. Der Zweck dieser Studie bestand in der Feststellung des Niveaus der Kommunikation mit den Kunden in ausgewählten Geschäftszweigen der Tschechischen Republik. Die Studie wurde in sechs Regionen sowohl in großen als auch kleinen Städten in Geschäften durchgeführt, welche für die Ermittlung des Niveaus der Kundenkommunikation ausgewählt worden waren. Die Ergebnisse der Studie zeigen, dass es während der letzten Jahre zu positiven Veränderungen des Verkaufsniveaus gekommen ist. Es wurde ebenfalls bestätigt, dass die Kundenkommunikation in kleineren Geschäften besser vonstatten geht als in großen. Die Ergebnisse sind wichtig für das Verkaufsmanagement, das Interesse an einer Verbesserung des Verkaufs hat. Sie sind hilfreich für die Ausbildung von Verkäufern und für die Steigerung der Verkaufsqualität.

\section{PODNOSZENIE JAKOŚCI USŁUG DLA KLIENTÓW POPRZEZ STOSOWANIE TECHNIKI MYSTERY SHOPPING}

Artykuł poświęcony jest jakości usług oferowanych klientom a w szczególności komunikacji sprzedażowej zorientowanej na klienta w Republice Czeskiej. Aby świadczyć wysokiej jakości usługi organizacja musi na bieżąco badać potrzeby i życzenia klientów oraz dokonywać kontroli procesu sprzedaży, w tym komunikacji zorientowanej na klienta. Celem pracy badawczej było stwierdzenie, jaki poziom komunikacji z klientami występuje w wybranych dziedzinach handlu w Republice Czeskiej. Badania prowadzono w sześciu regionach w małych i dużych miastach w sklepach, które wybrano w celu zdiagnozowania poziomu komunikacji zorientowanej na klienta. Wyniki badań wskazują na pozytywne zmiany w zakresie poziomu sprzedaży, jakie nastąpiły w ostatnich latach. Ponadto potwierdzono, że komunikacja z klientami jest lepsza w małych punktach sprzedaży aniżeli w dużych sklepach. Wyniki badań mają znaczenie dla zarządzających sprzedażą pod kątem jej doskonalenia. Można je także wykorzystać w celu szkolenia sprzedawców oraz w celu podnoszenia jakości sprzedaży. 